OPEN ACCESS

Edited by:

Suzie Chen,

Rutgers, The State University of New

Jersey, United States

Reviewed by:

Kevinn Eddy,

Rutgers, The State University of New

Jersey, United States

Endashaw Omer,

University of Louisville, United States

*Correspondence:

Jan-Malte Placke

Jan-Malte.Placke@uk-essen.de

Specialty section: This article was submitted to

Skin Cancer,

a section of the journal

Frontiers in Oncology

Received: 15 June 2021

Accepted: 23 July 2021

Published: 11 August 2021

Citation:

Placke J-M, Rawitzer J, Reis H,

Rashidi-Alavijeh J, Livingstone E, Ugurel S, Hadaschik E, Griewank K,

Schmid KW, Schadendorf $D$,

Roesch A and Zimmer L (2021)

Apoptotic Gastritis in Melanoma

Patients Treated With PD-1-Based

Immune Checkpoint Inhibition -

Clinical and Histopathological Findings Including the Diagnostic Value of Anti-

Caspase-3 Immunohistochemistry.

Front. Oncol. 11:725549.

doi: 10.3389/fonc.2021.725549

\section{Apoptotic Gastritis in Melanoma Patients Treated With PD-1-Based Immune Checkpoint Inhibition - Clinical and Histopathological Findings Including the Diagnostic Value of Anti-Caspase-3 Immunohistochemistry}

\author{
Jan-Malte Placke ${ }^{1 *}$, Josefine Rawitzer ${ }^{2}$, Henning Reis ${ }^{2}$, Jassin Rashidi-Alavijeh ${ }^{3}$, \\ Elisabeth Livingstone ${ }^{1}$, Selma Ugurel ${ }^{1}$, Eva Hadaschik ${ }^{1}$, Klaus Griewank ${ }^{1}$, \\ Kurt Werner Schmid ${ }^{2}$, Dirk Schadendorf ${ }^{1,4}$, Alexander Roesch ${ }^{1,4}$ and Lisa Zimmer ${ }^{1}$ \\ ${ }^{1}$ Department of Dermatology, University Hospital Essen, University of Duisburg-Essen, Essen, Germany, ${ }^{2}$ Institute of \\ Pathology, University Hospital Essen, University of Duisburg-Essen, Essen, Germany, ${ }^{3}$ Department of Gastroenterology and \\ Hepatology, University Hospital Essen, University of Duisburg-Essen, Essen, Germany, ${ }^{4}$ German Consortium of Translational \\ Cancer Research (DKTK), German Cancer Research Center (DKFZ), Heidelberg, Germany
}

Background: Gastritis induced by checkpoint inhibitors (CPI) is a rare but severe drugrelated side effect. The reference standard for confirming CPI-associated gastritis (CPIassGastritis) is histopathological assessment; however, the histopathological features of CPI-assGastritis are not yet adequately defined.

Materials and Methods: Gastric biopsies of melanoma patients with histopathologically suspected CPI-assGastritis were compared with gastric biopsies of patients with inflammation free gastric mucosa (IFGM), type $A, B$, and $C$ gastritis with respect to apoptosis count and predominant histopathological features. Immunohistochemical anticaspase-3 staining was performed to identify apoptosis. Quantification was performed by manually counting the number of apoptotic events per 10 high-power fields (HPF). Clinical symptoms, treatment, and follow-up data of patients with CPI-assGastritis were examined. The nonparametric Mann-Whitney $U$ test was used for statistical testing.

Results: Five melanoma patients (three women, two men; median age: 45 years) were treated with PD-1-based CPI. The patients reported epigastric pain, weight loss, nausea, and vomiting. Histologically, the patients with CPI-assGastritis showed a partly lymphocytic, partly granulocytic inflammatory infiltrate. Manual counting of apoptotic cells in biopsy tissue slides stained against caspase 3 revealed a median of 6 apoptotic events/10 HPF (95\% Cl, 2.75-17.30) in the patients with CPI-assGastritis. Results for the comparison cohort (patients $n=21$ ) were a median of 1 apoptotic event/10 HPF $(95 \% \mathrm{Cl}$, 0.5-4.5) for type-A gastritis (six patients), a median of 2 apoptotic events/10 HPF (95\% $\mathrm{Cl}, 0-4.5)$ for type-B gastritis (five patients), and no apoptosis for IFGM and type-C 
gastritis (five patients). Patients with $\mathrm{CPI}$-assGastritis had a significantly higher apoptosis count than patients with IFGM $(p<0.01)$, type $A(p<0.05), B(p<0.05)$, and $C$ gastritis $(p<0.01)$. None of the CPI-assGastritis biopsies showed evidence of Helicobacter pylori. All $\mathrm{CPI}$-assGastritis patients responded to systemic treatment with corticosteroids.

Conclusion: $\mathrm{CPI}$-assGastritis manifests with nonspecific symptoms but histologically shows a high number of apoptotic events, which can best be visualized by anti-caspase-3 immunohistochemistry. This histopathological feature may help to histologically differentiate CPI-assGastritis from other forms of gastritis and inform decision-making regarding its optimal management.

Keywords: melanoma, immune check inhibitor (ICI), PD-1, gastritis, immune related adverse effects

\section{INTRODUCTION}

The introduction of checkpoint inhibitors (CPI) as an antineoplastic treatment has led to an improvement in overall and progression-free survival for a wide range of tumors, e.g. nonsmall-cell lung cancer, Merkel cell carcinoma, and melanoma (1-3). Examples of CPI include programmed cell death protein 1 (PD-1), programmed cell death 1 ligand 1 (PD-L1), and cytotoxic T-lymphocyte-associated protein 4 (CTLA-4) antibodies. Furthermore, a combination therapy of nivolumab with the anti-CTLA-4 inhibitor ipilimumab is approved for treatment of non-small-cell lung cancer, renal cell carcinoma, and melanoma (4-6). Despite the improvement in progressionfree and overall survival, up to $21 \%$ of patients treated with antiPD-1-based monotherapy and up to $59 \%$ of patients treated with combined ipilimumab and nivolumab develop severe and lifethreatening immune-related adverse events (classified according to the Common Terminology Criteria for Adverse Events [CTCAE]; grade 3/4) $(7,8)$. Common immune-related adverse events (ir-AEs) include colitis, hepatitis, thyroiditis, and cutaneous side effects. Rarer ir-AEs include myocarditis, nephritis, neurological AEs, and gastritis (9-11). Correct and early diagnosis followed by rapid treatment is crucial to prevent life-threatening AEs and permanent damage to patients (12).

Early and correct diagnosis of rare side effects such as autoimmune gastritis after CPI is especially difficult for several reasons. First, CPI-associated gastritis (CPI-assGastritis) is associated with nonspecific symptoms such as exhaustion, nausea, epigastric pain, vomiting, and weight loss. It also requires differential diagnosis from gastritis types $\mathrm{A}, \mathrm{B}$, and $\mathrm{C}$, which have a high incidence in the general population. However, correct and early diagnosis is particularly important in the case of gastritis, because while steroids are the standard treatment for CPI-assGastritis, they are contraindicated for the common types of gastritis A, B, and C (13). Regarding patients who develop ircolitis after CPI, it has been known for a while that inflammation is associated with prominent apoptotic features in glandular epithelia (14). In late 2019, Johncilla et al. described an increased number of apoptotic events as part of the histological pattern of CPI-assGastritis (15). Apoptosis is the process of regulated cell death. It is activated by an intrinsic or extrinsic signaling pathway. The intrinsic pathway is activated by intracellular stress in the mitochondria. In contrast, the extrinsic pathway is activated by external stimuli such as ligands of death receptors (16).

In daily clinical practice, no histopathological classification of CPI-assGastritis exists that clearly distinguishes it from common forms of gastritis such as types A, B, and C. The following study investigates whether apoptosis count is a good marker to differentiate CPI-assGastritis from frequently observed type A, $\mathrm{B}$, and $\mathrm{C}$ gastritis. In addition, we evaluate patient and tumor characteristics, clinical symptoms, and treatment of patients with CPI-assGastritis.

\section{PATIENTS AND METHODS}

\section{Patient Data}

Melanoma patients with histopathologically suspected CPIassGastritis and patients with histopathologically confirmed inflammation free gastric mucosa (IFGM), type A, B, or C gastritis were included in the study. Histopathological diagnosis and tissue samples were provided by the Institute of Pathology of Essen University Hospital. Patient characteristics were obtained from the clinical database of Essen University Hospital. These characteristics included tumor stage, type of CPI, clinical symptoms, results of gastroscopy, therapy of side effects, and follow-up data from patients with CPI-assGastritis. All patients provided written, informed consent for their tissue to be examined. The study was approved by the ethics committee of Duisburg-Essen University and conducted in accordance with the Declaration of Helsinki. Human biological samples and related data were provided by the Westdeutsche Biobank Essen (WBE, Essen University Hospital, University of Duisburg-Essen, Essen, Germany, approval number 19-8705-BO).

\section{Immunohistochemical Staining and Examination}

Archived, formalin-fixed, paraffin-embedded (FFPE) biopsies of patients with suspected CPI-assGastritis were taken from the biobank of Essen University Hospital. The biopsies were taken during the acute phase of the patient's gastritis. Historical gastric biopsies of patients with confirmed IFGM, type A, B, and C 
gastritis, whose histopathological evaluation was complete, were used as a comparison cohort. These historical biopsies were taken from the Institute of Pathology, Essen University Hospital. The FFPE specimens were cut into $4-\mu \mathrm{m}$-thick consecutive slides of tissue. Routine hematoxylin\&eosin (H\&E) staining and anticaspase-3 immunohistochemical staining were performed (Caspase 3, Cell Signaling Technology Inc.; Danvers, MA). Histochemical Giemsa staining was used to assess the presence of Helicobacter pylori. Immunohistochemical staining was performed using the Autostainer Link 48 (Agilent Dako; Santa Clara, CA).

The number of intraepithelial apoptotic events in the gastric mucosa in an area measuring $6.25 \mathrm{~mm}^{2}$ (10 HPF) was counted manually and in a blinded fashion by an advanced pathologist of the Institute of Pathology, Essen University Hospital. The apoptotic cells located in the glandular lumen were not counted, as they are physiologically present there in inflammatory altered gastric mucosa.

\section{Statistical Analysis}

Statistical analysis was performed with GraphPad Prism (Version 8.4.3, GraphPad Software; San Diego, CA). For statistical testing, the nonparametric Mann-Whitney $U$ test was performed. Two-sided p-values were evaluated, and a p-value of $<0.05$ was considered statistically significant.

\section{RESULTS}

\section{Patient Characteristics}

A total of five melanoma patients (three women, two men) with histologically suspected CPI-assGastritis were included in the study. The comparison cohort comprised 21 patients: five with histologically confirmed IFGM, six with type-A gastritis and five patients each with type-B and -C gastritis. In the group with CPIassGastritis, the median age of the patients at onset of symptoms was 45 years (range 38-54). In the group of patients with IFGM, gastric biopsies were taken at a median age of 57 (range 46-64), in patients with type-A gastritis, gastric biopsies were taken at a median age of 58.5 years (range, 49-75); in patients with type-B gastritis, gastric biopsies were taken at a median age of 43 years (range, 39-72); and in patients with type-C gastritis, gastric biopsies were taken at a median age of 52 years (range, 46-69). Patients with IFGM were female in $80 \%$ and male in $20 \%$, type A gastritis were all female, and those with type $\mathrm{B}$ and type $\mathrm{C}$ gastritis were each $80 \%$ male and $20 \%$ female. All five CPIassGastritis patients received combined CPI treatment (ipilimumab + nivolumab [n=3], pembrolizumab + epacadostat $[n=1]$, nivolumab + relatlimab $[n=1])$ for stage IV metastatic melanoma. In addition, four of these five patients had other CPI-related ir-AEs, such as hepatitis, lichen ruber, or thyroiditis, and these occurred either shortly before or concurrently with gastritis (Table 1). All CPI-assGastritis patients manifested clinical symptoms, the most common of which were nausea and vomiting, epigastric pain, and weight loss. The median time between start of treatment and onset of clinical symptoms of CPI-assGastritis was 118 days (range 29336 days). Detailed characteristics of the patients with CPIassGastritis are listed in Table $\mathbf{1 .}$

\section{Endoscopic Results}

A gastroscopy with guideline biopsies was performed on all five patients with CPI-assGastritis. The median time between onset of clinical symptoms and gastroscopy was 13 days (range 2-5 days). Macroscopically, four of the five patients CPI-assGastritis showed severe findings with partly edematous erythematous and partly hemorrhagic components in gastroscopy (Table 2 and Figure 1A). One patient's macroscopic finding was classified as moderate with partly striated erythematous mucosal changes (Table 2 and Figure 1B). As a healthy comparison sample, Figure 1C shows the microscopic image of a patient with normal gastric mucosa.

\section{Conventional Histochemical Staining}

Routine H\&E diagnostic staining showed evidence of numerous apoptotic events in the glandular epithelia of all five patients treated with CPI. Furthermore, a partly lymphocytic, partly granulocytic inflammatory infiltrate with pronounced foveolar abscesses was found. Helicobacter pylori was not detected in any of the CPI patients' biopsies in Giemsa staining but was found in five patients (all type- $B$ gastritis) in the control group. In contrast, patients in the comparison cohort with IFGM showed no apoptotic features, patients with common A and B forms of gastritis only showed evidence of isolated apoptotic features in routine HE staining. No apoptosis was found in the patients with type $\mathrm{C}$ gastritis. The histologic features of the distinct forms of gastritis are summarized in Table 3. Overall, it was not possible to definitively classify glandular epithelial cells as apoptotic by means of H\&E staining alone as lymphocytes and granulocytes migrating into the gland can exhibit a very similar cell morphology (Figure 2).

\section{Immunohistochemical Anti-Caspase-3 Staining Confirmed That the Number of Apoptotic Events Was Higher in CPI- ass Gastritis Than in Common Types of Gastritis}

Immunohistochemical anti-caspase-3 staining was performed to identify apoptotic events. In patients with CPI-assGastritis, staining showed numerous apoptotic events both in the cell layer of the glandular epithelia and in detached cells shifted to the lumen of the gland (Table 3). In comparison, patients with IFGM showed no apoptosis, patients with type A and type B gastritis showed only isolated apoptotic features in the glandular cell layer and no detached apoptotic cells in the glandular lumen. No apoptosis was observed in patients with type C gastritis (Figure 3).

Manual counting of caspase-3-positive cells revealed a median of 6 apoptotic events/10 HPF (95\% CI, 2.75-17.30) in patients with CPI-assGastritis, no apoptosis in patients with IFGM, a median of 1 apoptotic event/10 HPF (95\% CI, 0.54.5 ) in patients with type A gastritis, a median of 2 apoptotic 
TABLE 1 | Characteristics of melanoma patients with CPI-associated gastritis.

\begin{tabular}{|c|c|c|c|c|c|}
\hline Patient & 1 & 2 & 3 & 4 & 5 \\
\hline Stage (AJCC, eighth edition) & IV & IV & IV & IV & IV \\
\hline Age & 41 & 38 & 45 & 54 & 52 \\
\hline Sex & Female & Male & Male & Female & Female \\
\hline Other autoimmune events & $\begin{array}{l}\text { Hepatitis } \\
\text { (concurrent with } \\
\text { gastritis) }\end{array}$ & $\begin{array}{l}\text { Lichen ruber } \\
\text { ( } 4 \text { months before } \\
\text { gastritis) }\end{array}$ & $\begin{array}{l}\text { Hypophysitis } \\
\text { Thyroiditis } \\
\text { ( } 2 \text { months before } \\
\text { gastritis) }\end{array}$ & $\begin{array}{l}\text { Thyroiditis } \\
\text { (3 months before } \\
\text { gastritis) }\end{array}$ & None \\
\hline Weight loss & None & $9 \mathrm{~kg}$ in $3 \mathrm{w}$ & $10 \mathrm{~kg}$ in $3 \mathrm{w}$ & $8 \mathrm{~kg}$ in $3 \mathrm{w}$ & None \\
\hline \multirow[t]{2}{*}{ Clinical symptoms } & Nausea & Nausea & Heartburn & Nausea & \\
\hline & Vomiting & $\begin{array}{l}\text { Vomiting } \\
\text { Epigastric pain }\end{array}$ & $\begin{array}{l}\text { Appetite loss } \\
\text { Nausea }\end{array}$ & Vomiting & Hemoglobin loss \\
\hline $\begin{array}{l}\text { Time between start of CPI and occurrence of } \\
\text { symptoms (days) }\end{array}$ & 29 & 336 & 118 & 166 & 50 \\
\hline Last therapy before onset of gastritis & $\begin{array}{l}\text { Ipilimumab and } \\
\text { nivolumab }\end{array}$ & $\begin{array}{l}\text { Pembrolizumab and } \\
\text { epacadostat }\end{array}$ & Nivolumab & $\begin{array}{l}\text { Nivolumab and } \\
\text { relatlimab }\end{array}$ & $\begin{array}{l}\text { Ipilimumab and } \\
\text { nivolumab }\end{array}$ \\
\hline Previous therapies & None & None & $\begin{array}{l}\text { Ipilimumab/ } \\
\text { nivolumab }\end{array}$ & None & $\begin{array}{l}\text { BRAF/MEK } \\
\text { inhibition }\end{array}$ \\
\hline
\end{tabular}

AJCC, American Joint Committee on Cancer; CPI, checkpoint inhibition; w, weeks.

TABLE 2 | Clinical, endoscopic, and histological characteristics and clinical course of patients with CPI-associated gastritis.

\begin{tabular}{|c|c|c|c|c|c|}
\hline Patient & Endoscopic features & $\begin{array}{l}\text { Histopathological } \\
\text { features }\end{array}$ & $\begin{array}{l}\text { Treatment for } \\
\text { ir-gastritis }\end{array}$ & Subsequent therapies & $\begin{array}{c}\text { Autoimmune side effects after } \\
\text { re-challenge }\end{array}$ \\
\hline 1 & Moderate pangastritis & $\begin{array}{l}\text { Lymphocytes } \\
\text { Plasma cells } \\
\text { Granulocytes } \\
\text { Erosive mucosa } \\
17 \text { apoptoses/10 } \\
\text { HPF }\end{array}$ & $\begin{array}{l}\text { Pantoprazole } 40 \text { mg 2x/day } \\
\text { Prednisolone } 1 \mathrm{mg} / \mathrm{kg} \mathrm{bw}\end{array}$ & Dabrafenib plus trametinib & No re-challenge with $\mathrm{CPI}$ \\
\hline 2 & Severe erosive pangastritis & $\begin{array}{l}\text { Lymphocytes } \\
\text { Plasma cells } \\
\text { Granulocytes } \\
4 \text { apoptoses/10 HPF }\end{array}$ & $\begin{array}{l}\text { Pantoprazole } 40 \text { mg 2x/day } \\
\text { Prednisolone } 1 \mathrm{mg} / \mathrm{kg} \mathrm{bw}\end{array}$ & Nivolumab plus relatlimab & $\begin{array}{l}\text { No immune-related adverse } \\
\text { events }\end{array}$ \\
\hline 3 & $\begin{array}{l}\text { Severe erythematous } \\
\text { pangastritis }\end{array}$ & $\begin{array}{l}\text { Lymphocytes } \\
\text { Plasma cells } \\
\text { Granulocytes } \\
\text { Ulcerations } \\
6 \text { apoptoses/10 HPF }\end{array}$ & $\begin{array}{l}\text { Pantoprazole } 40 \text { mg 2×/day } \\
\text { Prednisolone } 1 \mathrm{mg} / \mathrm{kg} \mathrm{bw}\end{array}$ & $\begin{array}{l}\text { Pembrolizumab plus } \\
\text { domatinostat }\end{array}$ & $\begin{array}{l}\text { No immune-related adverse } \\
\text { events }\end{array}$ \\
\hline 4 & $\begin{array}{l}\text { Severe pangastritis, } \\
\text { separation of the gastric } \\
\text { mucosa }\end{array}$ & $\begin{array}{l}\text { Lymphocytes } \\
\text { Plasma cells } \\
\text { Granulocytes } \\
14 \text { apoptoses/10 } \\
\text { HPF }\end{array}$ & $\begin{array}{l}\text { Dexamethasone } 8 \mathrm{mg} \\
\text { Metoclopramide } 10 \mathrm{mg} \mathrm{2 \times /} \\
\text { day } \\
\text { Pantoprazole } 40 \mathrm{mg} 2 \times / \text { day }\end{array}$ & Nivolumab & $\begin{array}{l}\text { No immune-related adverse } \\
\text { events }\end{array}$ \\
\hline 5 & Severe hemorrhagic pangastritis & $\begin{array}{l}\text { Lymphocytes } \\
\text { Plasma cells } \\
\text { Granulocytes } \\
\text { Intestinal metaplasia } \\
3 \text { apoptoses/10 HPF }\end{array}$ & $\begin{array}{l}\text { Pantoprazole } 40 \text { mg 2x/day } \\
\text { Prednisolone } 1 \mathrm{mg} / \mathrm{kg} \text { bw }\end{array}$ & $\begin{array}{l}\text { Nivolumab } \\
\text { Binimetinib plus encorafenib }\end{array}$ & $\begin{array}{l}\text { No immune-related adverse } \\
\text { events }\end{array}$ \\
\hline
\end{tabular}

CPI, checkpoint inhibition; ir, immune-related. bw, bodyweight; HPF, high power field.

events/10 HPF (95\% CI, 0-4.5) in patients with type B gastritis, and no apoptosis in patients with type-C gastritis. Patients with CPIassGastritis had a significantly higher number of apoptotic events than patients with IFGM $(\mathrm{p}<0.01)$ type A gastritis $(\mathrm{p}<0.05)$, type-B gastritis $(\mathrm{p}<0.05)$, and type- $\mathrm{C}$ gastritis $(\mathrm{p}<0.01$; Figure 4$)$.

\section{Management of CPI-assGastritis and Further Clinical Course}

All CPI-assGastritis patients received systemic treatment with high-dose corticosteroids. Four patients received $1 \mathrm{mg}$ methylprednisolone per $\mathrm{kg}$ bodyweight: three patients intravenously (i.v.) and one per os (p.o.). One patient received $8 \mathrm{mg}$ i.v. dexamethasone per day. Furthermore, all patients were treated with $40 \mathrm{mg}$ pantoprazole twice per day. Metoclopramide and dimenhydrinate were administered intravenously to three of five patients as an antiemetic treatment. Treatment led to rapid improvement of clinical symptoms after a median of 6 days (range 2-7 days). Except for corticosteroids, no further immunosuppression was necessary. After resolution of symptoms, four of the five patients were subsequently 


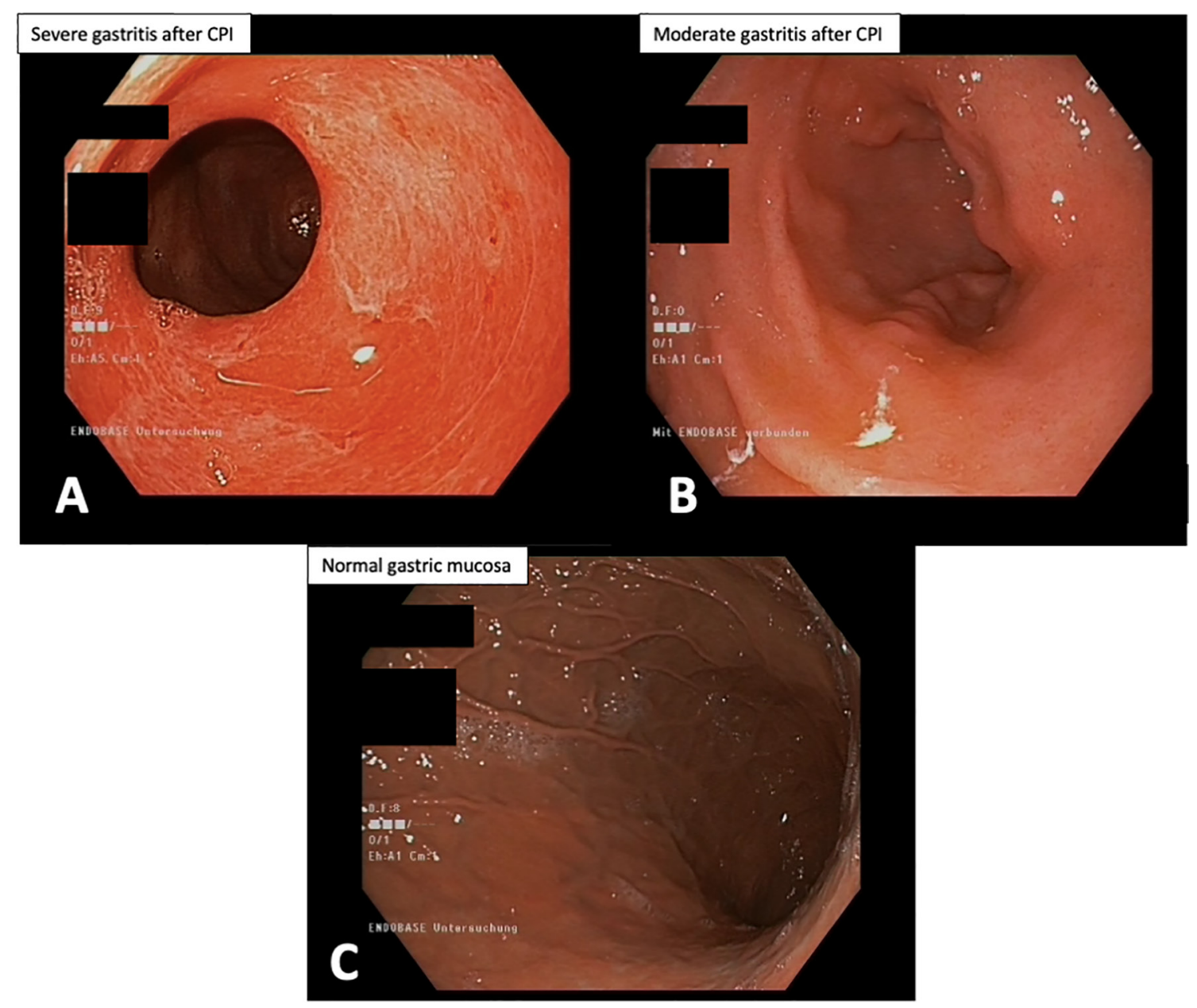

FIGURE 1 | Examples of gastroscopy of two patients with CPI-associated gastritis. (A) Gastroscopy revealed erosive pangastritis and marked replacement of gastric mucosa. (B) Gastroscopy shows a case of a non-erosive pangastritis. (C) Gastroscopy shows normal gastric mucosa without inflammation. CPI, checkpoint inhibition.

rechallenged with PD1-based CPI. None of the patients had a second episode of CPI-assGastritis (Table 2).

\section{Selected Patient Cases Demonstrating the Diversity of the Clinical Picture of CPI-assGastritis}

Case 1: A 38-year-old patient was diagnosed with stage IV melanoma with pulmonary metastases and iliac lymph node metastases. After receiving a total of 17 infusions of pembrolizumab in combination with epacadostat within a clinical trial (NCT02752074), the patient reported gastric pain, vomiting, and lack of appetite, as well as involuntary weight loss of $9 \mathrm{~kg}$ over 3 weeks. Gastroscopy showed signs of erosive pangastritis with distinct, diffusely erythematous as well as edematous mucosa throughout the stomach. The patient also had numerous confluent shallow erosions (maximum diameter: approximately $5 \mathrm{~mm}$ ) throughout the stomach without evidence of previous bleeding (Figure 5A). Several samples were taken during gastroscopy. Histologic analysis revealed severe chronic and active ulcerative inflammation with infiltrates of lymphocytes, plasma cells, and neutrophils (Figure 5B). Treatment with $1 \mathrm{mg}$ p.o. methylprednisolone per kg body weight and $40 \mathrm{mg}$ pantoprazole i.v. twice daily was immediately started. This resulted in marked improvement of the patient's clinical symptoms after 3 days. Four weeks later, a follow-up gastroscopy with histopathological analysis of biopsies was performed; this showed only a discrete gastritis in the prepyloric antrum with histologic features of a low-grade active gastritis (Figures 5C, D). After disease progression, the patient was treated with nivolumab in combination with relatlimab (NCT01968109) without recurrence of CPI-assGastritis.

Case 2: A 45-year-old male patient with stage IV melanoma who had received four doses of ipilimumab and nivolumab followed by two doses of nivolumab for bipulmonary metastases presented with severe heartburn, lack of appetite, nausea, and weight loss of approximately $10 \mathrm{~kg}$ over 3 weeks. Because the patient was no longer able to achieve adequate food intake, he was admitted to hospital for further evaluation. Subsequent gastroscopy revealed pronounced erythematous pangastritis with marked diffuse, 
TABLE 3 | Histological features of the different forms of gastritis.

\begin{tabular}{|c|c|c|c|c|}
\hline & Type A gastritis & Type B gastritis & Type C gastritis & CPI-ass Gastritis \\
\hline $\begin{array}{l}\text { Inflammatory } \\
\text { infiltrate }\end{array}$ & $\begin{array}{l}\text { Lymphoplasmacytic- } \\
\text { dominant inflammatory } \\
\text { infiltrate }\end{array}$ & $\begin{array}{l}\text { Mixed inflammatory infiltrate } \\
\text { with a usually superficial } \\
\text { granulocytic component } \\
\text { close to the crypt lumina }\end{array}$ & $\begin{array}{l}\text { Lymphoplasmacytic inflammatory infiltrate, } \\
\text { sparse amount of intermingling neutrophilic } \\
\text { granulocytes possible }\end{array}$ & $\begin{array}{l}\text { Mixed inflammatory infiltrate with } \\
\text { lymphoplasmacytic and granulocytic } \\
\text { component, foveolar abscess formation } \\
\text { possible }\end{array}$ \\
\hline apoptosis & $\begin{array}{l}\text { Mild increase of } \\
\text { apoptotic cells in the } \\
\text { gland epithelia (average } \\
\text { of } 1 \text { apoptotic cell per } \\
10 \mathrm{HPF} \text { ) }\end{array}$ & $\begin{array}{l}\text { Mild increase of apoptotic } \\
\text { cells in the gland epithelia } \\
\text { (average of } 1.5 \text { apoptotic } \\
\text { cells per } 10 \text { HPF) }\end{array}$ & $\begin{array}{l}\text { No increase of apoptotic cells in the gland } \\
\text { epithelia }\end{array}$ & $\begin{array}{l}\text { Increase of apoptotic cells in the gland } \\
\text { epithelia, detachment of apoptotic cells } \\
\text { and shift to the glandular lumen (average } \\
\text { of } 6 \text { apoptotic cells per } 10 \text { HPF) }\end{array}$ \\
\hline $\begin{array}{l}\text { Additional } \\
\text { characteristics }\end{array}$ & $\begin{array}{l}\text { Reduction/loss of } \\
\text { parietal cells and } \\
\text { hypoplasia of the } \\
\text { glandular body in corpus } \\
\text { mucosa }\end{array}$ & $\begin{array}{l}\text { Detection of Helicobacter } \\
\text { pylori via conventional H\&E- } \\
\text { and Giemsa stain, or } \\
\text { immunohistochemistry }\end{array}$ & $\begin{array}{l}\text { Fibrotic antral changes, foveolar hyperplasia, } \\
\text { smooth muscle fibers radiating to surface parts, } \\
\text { potentially intestinal type goblet cell metaplasia } \\
\text { and occurence of pseudo-Paneth cells. }\end{array}$ & $\begin{array}{l}\text { Anti-caspase } 3 \text { immunohistochemistry } \\
\text { helpful in detection of apoptotic bodies/ } \\
\text { cells. }\end{array}$ \\
\hline
\end{tabular}

HPF, High Power Field.

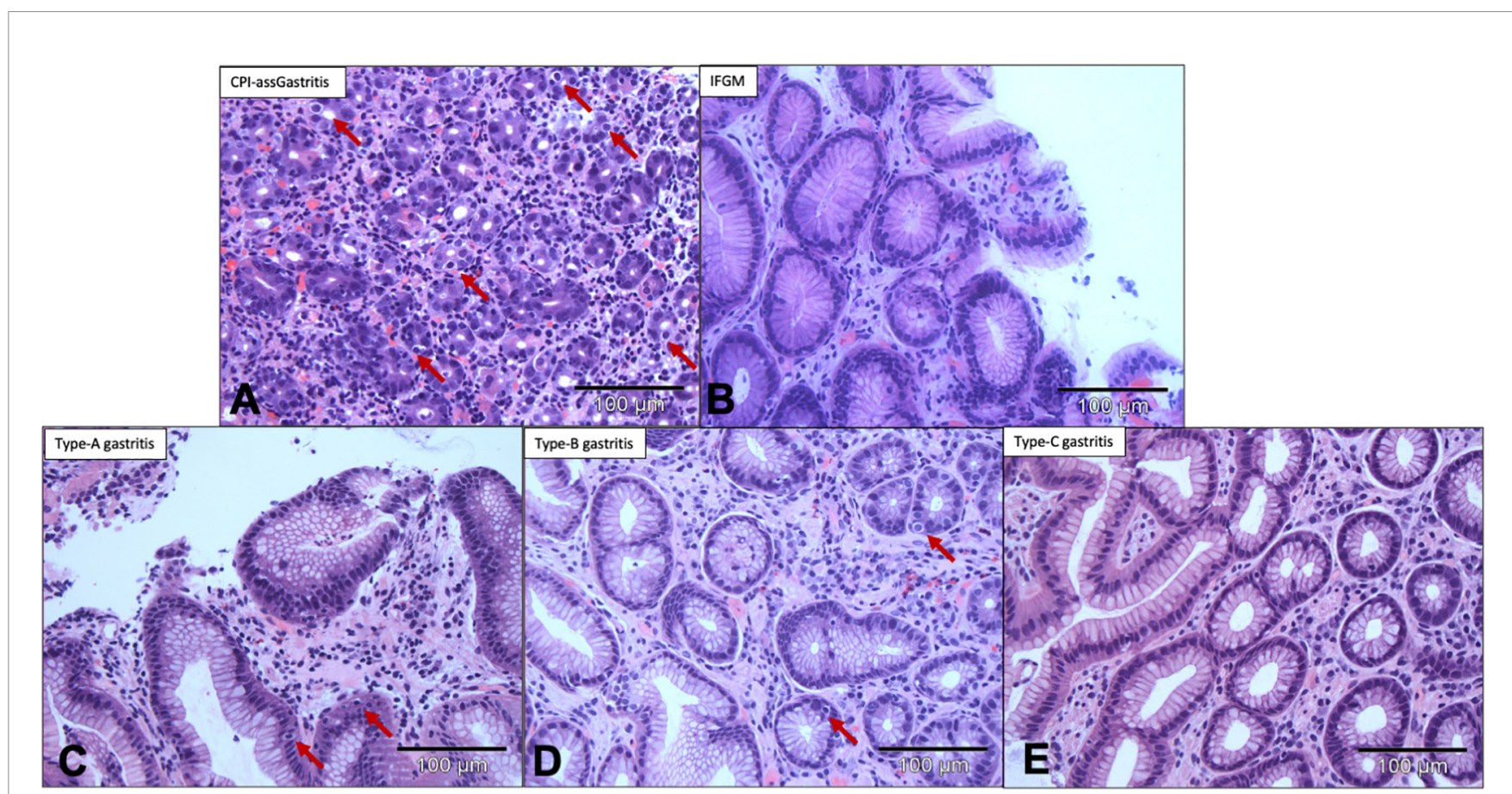

FIGURE 2 | Conventional H\&E staining suggests significant differences in frequency of apoptosis between CPI-associated gastritis and common types of gastritis. (A) Histological H\&E image of CPI-associated gastritis shows numerous suspected apoptotic events in the glandular epithelia. (B) IFGM without suspected apoptotic events, (C) Type-A and (D) type-B gastritis with isolated suspected apoptotic events in the glandular epithelia. (E) Type-C gastritis with no suspected apoptosis in the glandular epithelia. H\&E staining at 200x magnification. $\rightarrow$, apoptosis; CPI, checkpoint inhibition; H\&E, hematoxylin\&eosin staining; IFGM, Inflammation free gastric mucosa.

patchy-to-streaky and edematous mucosa with prominent fibrinous deposits throughout the stomach (Figure 6A). Sample biopsies taken during the gastroscopy histologically showed ulcerative high-florid pangastritis (Figure 6B). CPI-assGastritis was suspected, and the patient therefore received i.v. methylprednisolone $(1 \mathrm{mg} / \mathrm{kg} /$ day), i.v. pantoprazole (40 mg twice per day), and-because intake of solid food was no longer possible-a liquid diet. After 5 days there was a noticeable improvement, and the patient was able to eat solid food again.
After 9 days in hospital, the patient could be discharged. Follow-up gastroscopy performed 3 months later revealed an overall improvement but ongoing presence of chronic pangastritis with marked diffuse, patchy reddened and edematous mucosa throughout the stomach (Figure 6C). Specimen biopsies histologically showed moderate to severe chronic gastritis with predominantly lymphoplasmacytic cells and occasional neutrophils (Figure 6D). Subsequent staging showed progressive disease, and the patient received pembrolizumab in combination with the 


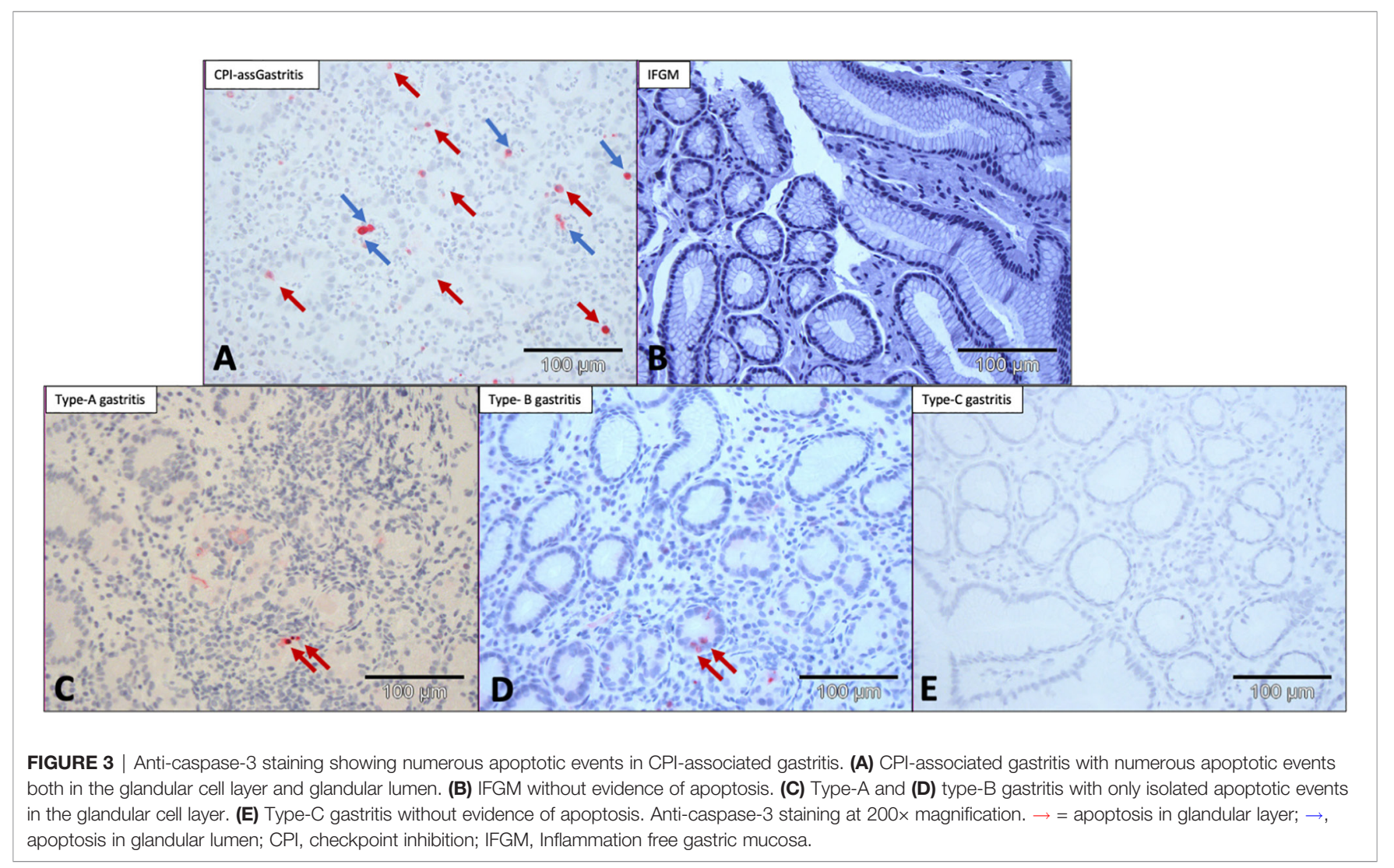

apoptosis in glandular lumen; CPI, checkpoint inhibition; IFGM, Inflammation free gastric mucosa.

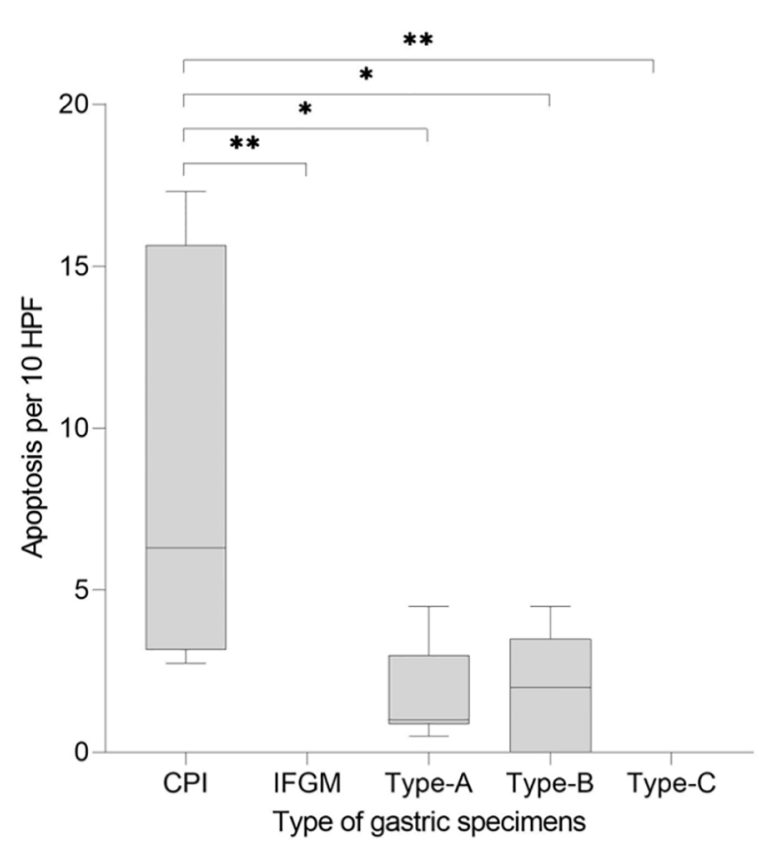

FIGURE 4 | Comparison of CPI-associated gastritis with common forms of gastritis regarding apoptosis rate. The y-axis shows the number of apoptotic events per 10 HPF. The $x$-axis shows the different types of gastritis (CPI-associated, IFGM, type A, type B, and type C). CPI-associated gastritis shows a significantly higher apoptosis rate. CPI, checkpoint inhibition; HPF, high-power field; IFGM, Inflammation free gastric mucosa; ${ }^{*} \mathrm{p}<0.05$; ${ }^{* *} \mathrm{p}<0.01$. 


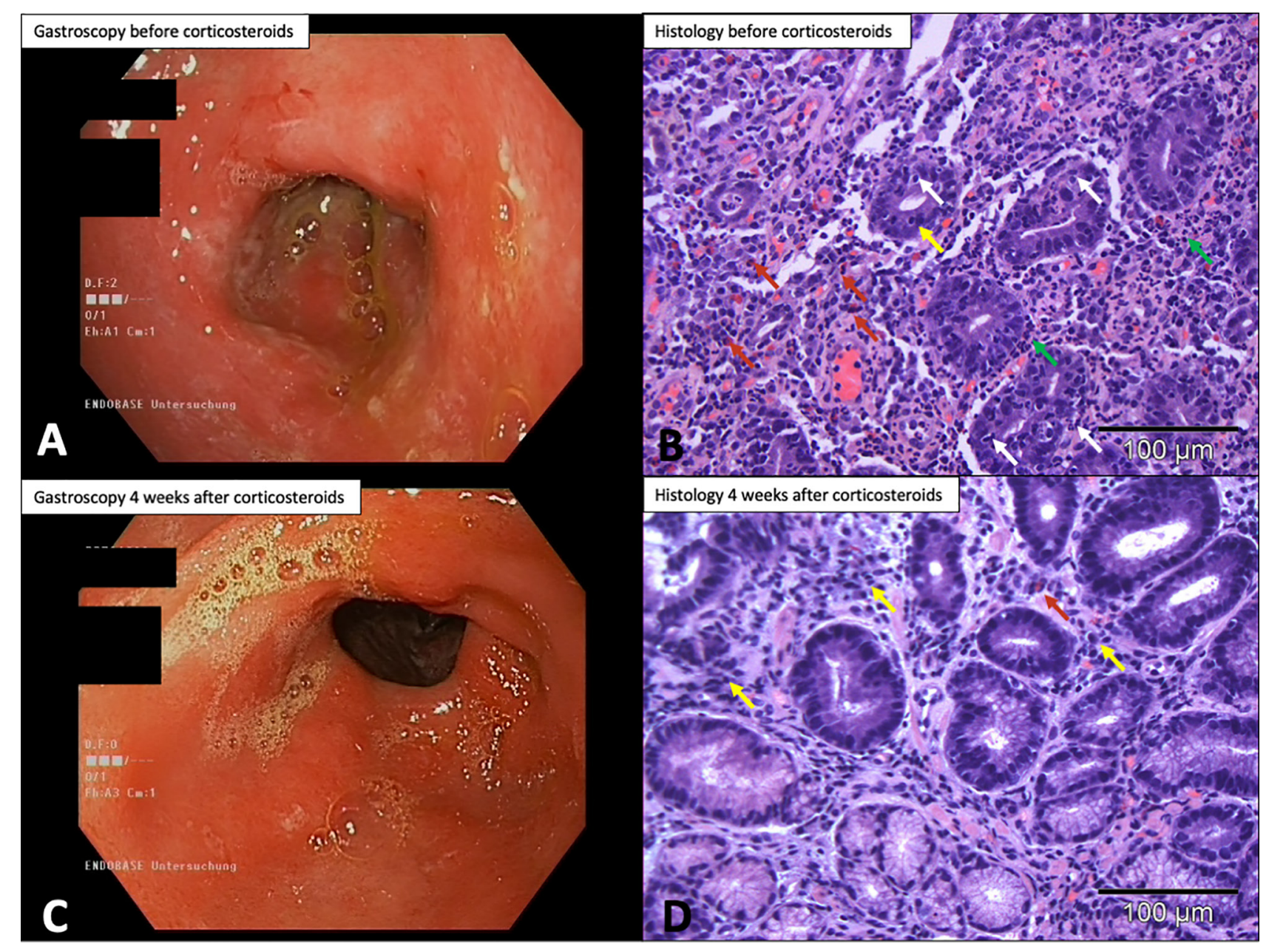

FIGURE 5 | Case 1: gastroscopy and histologic findings. (A) Gastroscopy before initiation of corticosteroids with signs of erosive pangastritis. (B) Biopsy before corticosteroids with severe inflammation of the antral mucosa, lymphocyte infiltrates, eosinophilic and neutrophilic granulocytes, and numerous apoptotic events (H\&E, 200x magnification). (C) Gastroscopy 4 weeks after corticosteroids showing marked improvement of inflammation and discrete prepyloric antrum gastritis. (D) Specimen biopsy 4 weeks after corticosteroids showing low lymphoplasmacytic cell infiltrate in the stroma and only isolated eosinophilic granulocytes (H\&E, 200x magnification). H\&E, hematoxylin\&eosin staining; $\mathbf{\rightarrow}$, apoptosis; $\rightarrow$, eosinophilic granulocytes; $\rightarrow$, neutrophilic granuolocytes; $\rightarrow$, lymphocytes.

histone deacetylase inhibitor domatinostat (NCT03278665) without further recurrence of CPI-assGastritis. Three months later the patient died from his progressive disease.

\section{DISCUSSION}

CPI-assGastritis is currently a rare but serious side effect of immune checkpoint blockade, and early diagnosis is often difficult because of nonspecific symptoms and the lack of clear histopathological classification. In our analysis, we examined the number of apoptotic events in the glandular epithelia of the stomach in patients with CPI-assGastritis and compared them for the first time with common type $\mathrm{A}, \mathrm{B}$, and $\mathrm{C}$ gastritis. We found a significantly higher rate of apoptosis in patients with CPIassGastritis than in patients with common types of gastritis, which highlights the value of classic histopathology in combination with anti-Caspase 3 IHC.

Clinically, patients in our cohort with CPI-assGastritis showed a heterogeneous pattern of disease with a wide spectrum of epigastric symptoms ranging from mild malaise and nausea to severe epigastric pain and vomiting. In contrast to previously published case series, $60 \%$ of our patients experienced extreme weight loss $(9,11,15,17,18)$. In the present study, all patients received dual CPI before the development of gastritis. This finding is highly consistent with observations in the literature. First, high-grade ir-AEs of grade 3 and 4 are known to occur significantly more frequently in melanoma patients on dual CPI of ipilimumab and nivolumab (58\%) than in those receiving anti-PD1 monotherapy (23\%) (19). Also, in the largest case collection on CPI-assGastritis to date, which studied a total of 12 patients, most patients received dual CPI (15). However, 


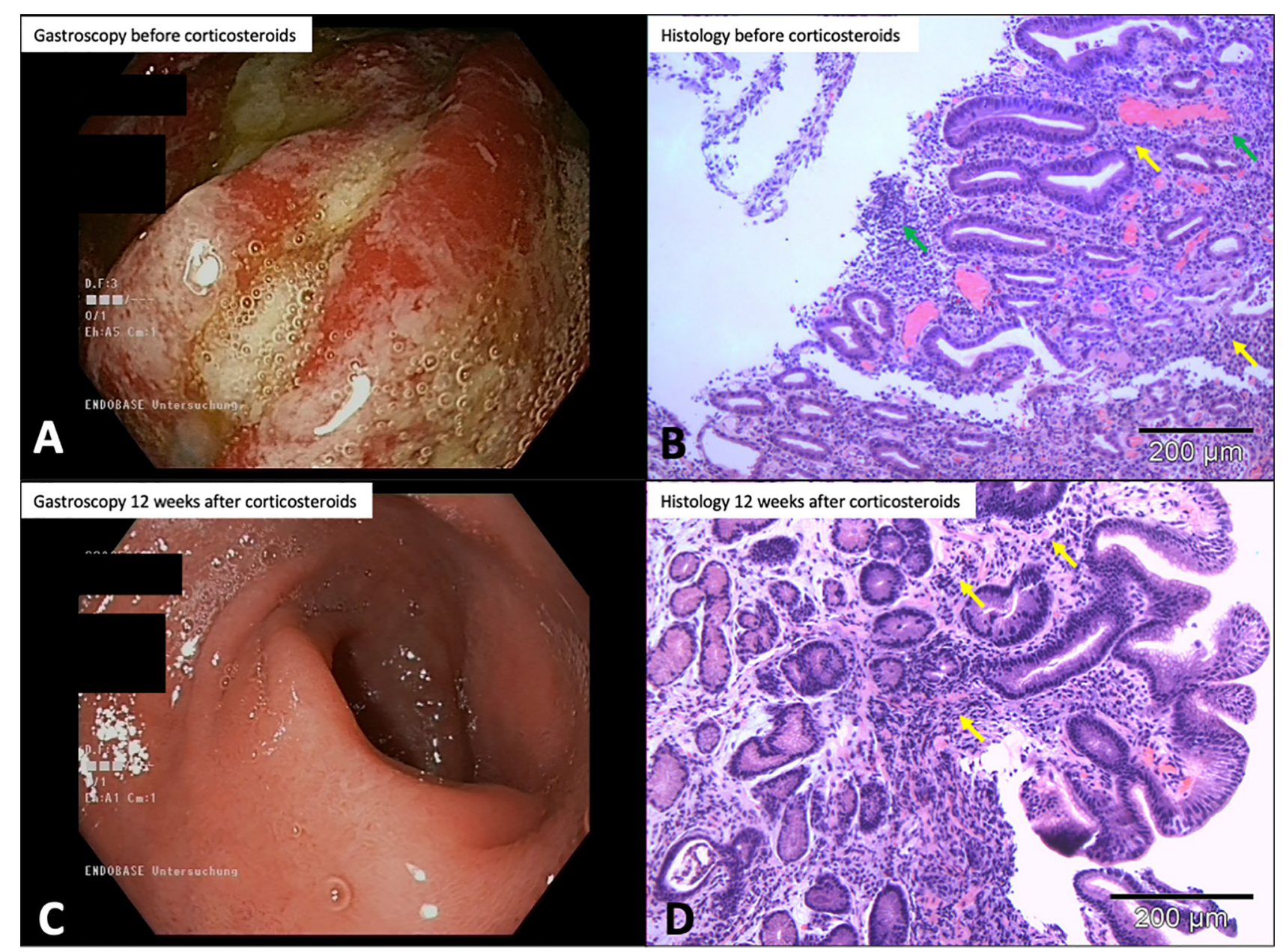

FIGURE 6 | Case 2: gastroscopy and histologic findings. (A) Gastroscopy before corticosteroids showing marked erythematous pangastritis. (B) Sample biopsy before corticosteroids showing partly lymphocytic, partly granulocytic inflammatory infiltrate with superficial ulceration, hyperemia, and vascular ectasia (H\&E, 100x magnification). (C) Gastroscopy 12 weeks after initiation of therapy showing marked improvement of chronic pangastritis. (D) Trial biopsy after therapy shows less stromal infiltrate than (C), but a small patchy inflammatory infiltrate of the glandular epithelium remains (H\&E, 100× magnification). H\&E, hematoxylin\&eosin staining, $\rightarrow$, neutrophilic granuolocytes; - , lymphocytes.

the development of CPI-assGastritis is not solely associated with dual CPI. Several case reports in the literature describe gastritis after anti-PD1 monotherapy $(11,17,18)$. Nevertheless, it is important for oncologists to be aware that dual CPI certainly increases the likelihood of developing CPI-assGastritis, especially because new indications for dual CPI are currently advancing rapidly. In addition to melanoma, dual CPI is now approved for renal cell carcinoma and non-small cell lung carcinoma, and additional approvals may soon follow (4-6).. Therefore, severe cases of CPI-assGastritis are expected to become more common in oncology patients in the near future. Early detection of CPIassGastritis is essential for the patient, because high-dose steroid therapy is indicated, whereas it is absolutely contraindicated for the other common forms of gastritis.

Because macroscopic appearance in gastroscopy does not enable reliable diagnosis of CPI-assGastritis, histopathological differentiation is of utmost importance. In particular, the typical histopathological pattern with a high rate of apoptoses observed in CPI-associated gastrointestinal side effects may help to distinguish CPI-assGastritis from other forms of gastritis. In contrast to previous studies on CPI-assGastritis in which apoptosis was quantified by means of H\&E staining (15), we used immunohistochemical anti-caspase-3 staining, by which apoptosis can be reliably detected. The pattern of increased apoptosis rate has long been described for CPI-associated colitis $(13,14,20)$. Another disease associated with increased apoptosis rates in the context of inflammation of the gastrointestinal tract is graft-versus-host disease (GvHD) (21-23). This raises the exciting question of whether the gastrointestinal side effect associated with CPI is similar to that seen in GvHD on the molecular level. The hypothesis of a molecular pathological relationship between the two diseases is supported not only by pronounced apoptosis rate, but 
also by the presence of a distinct inflammatory infiltrate consisting of extended lymphocytes, granulocytes, and cryptic or foveolar abscesses (9, 15, 20, 22, 24). Furthermore, CPI-associated gastrointestinal side effects and GvHD have similar treatment regimens consisting of immunosuppression in conjunction with primarily high-dose corticosteroids $(25,26)$.

Limitations of our study are its retrospective character and small cohort size. In addition, quantification of apoptosis was performed subjectively by hand counting rather than digital quantification. Unfortunately, apoptotic cells are physiologically present in the lumen of gastric glands during inflammatory processes, so they should not be used for quantification in CPI-assGastritis and hand counting is more reasonable. Nevertheless, due to the high clinical relevance of this topic and lack of information from randomized studies, we consider it important to report the clinical and histopathological observations of patients with CPI-assGastritis.

In conclusion, CPI-assGastritis is a challenge for the treating oncologist in terms of correct and early diagnosis. In patients treated with CPI, CPI-assGastritis should always be considered as the cause of unexplained epigastric symptoms. Diagnostic gastroscopy with specimen biopsies for histologic evaluation should be performed as soon as possible. The number of apoptotic events might help to histologically differentiate CPIassGastritis from common type $\mathrm{A}, \mathrm{B}$, and $\mathrm{C}$ gastritis, and should be included in the pathology report when CPI-assGastritis is suspected. In this context, anti-caspase- 3 immunohistochemistry is a helpful tool to precisely detect the extent of apoptotic cells. It is expected that this clinical picture, which is currently rarely observed, will become more common in the near future due to the increasing use of dual CPI for different tumor types.

\section{REFERENCES}

1. Brahmer J, Reckamp KL, Baas P, Crinò L, Eberhardt WEE, Poddubskaya E, et al. Nivolumab Versus Docetaxel in Advanced Squamous-Cell Non-SmallCell Lung Cancer. N Engl J Med (2015) 373:(2):123-35. doi: 10.1056/ NEJMoa1504627

2. Kaufman HL, Russell J, Hamid O, Bhatia S, Terheyden P, D’Angelo SP, et al. Avelumab in Patients With Chemotherapy-Refractory Metastatic Merkel Cell Carcinoma: A Multicentre, Single-Group, Open-Label, Phase 2 Trial. Lancet Oncol (2016) 17(10):1374-85. doi: 10.1016/S1470-2045(16)30364-3

3. Robert C, Long GV, Brady B, Dutriaux C, Maio M, Mortier L, et al. Nivolumab in Previously Untreated Melanoma Without BRAF Mutation. N Engl J Med (2014) 372(4):320-30. doi: 10.1056/NEJMoa1412082

4. Hellmann MD, Paz-Ares L, Bernabe Caro R, Zurawski B, Kim SW, Carcereny Costa E, et al. Nivolumab Plus Ipilimumab in Advanced NonSmall-Cell Lung Cancer. N Engl J Med (2019) 381(21):2020-31. doi: 10.1056/NEJMoa1910231

5. Motzer RJ, Rini BI, McDermott DF, Arén Frontera O, Hammers HJ, Carducci MA, et al. Nivolumab Plus Ipilimumab Versus Sunitinib in First-Line Treatment for Advanced Renal Cell Carcinoma: Extended Follow-Up of Efficacy and Safety Results From a Randomised, Controlled, Phase 3 Trial. Lancet Oncol (2019) 20(10):1370-85. doi: 10.1016/S1470-2045(19)30413-9

6. Larkin J, Chiarion-Sileni V, Gonzalez R, Grob JJ, Cowey CL, Lao CD, et al. Combined Nivolumab and Ipilimumab or Monotherapy in Untreated Melanoma. N Engl J Med (2015) 373(1):23-34. doi: 10.1056/NEJMoa1504030

7. Schachter J, Ribas A, Long GV, Arance A, Grob J-J, Mortier L, et al. Pembrolizumab Versus Ipilimumab for Advanced Melanoma: Final Overall Survival Results of a Multicentre, Randomised, Open-Label Phase 3 Study (KEYNOTE-006). Lancet (2017) 390(10105):1853-62. doi: 10.1016/S01406736(17)31601-X

\section{DATA AVAILABILITY STATEMENT}

The raw data supporting the conclusions of this article will be made available by the authors, without undue reservation.

\section{ETHICS STATEMENT}

The study was approved by the ethics committee of DuisburgEssen University and conducted in accordance with the Declaration of Helsinki. Human biological samples and related data were provided by the Westdeutsche Biobank Essen (WBE, Essen University Hospital, University of Duisburg-Essen, Essen, Germany, approval number 19-8705-BO). The patients/ participants provided their written informed consent to participate in this study.

\section{AUTHOR CONTRIBUTIONS}

J-MP and LZ analyzed and interpreted the patient data and were major contributors to writing the manuscript. JR and HR performed the histological examinations. JR-A was responsible for the gastroscopy. All authors contributed to the article and approved the submitted version.

\section{ACKNOWLEDGMENTS}

The authors are indebted to all patients and their relatives.

8. Basch E, Reeve BB, Mitchell SA, Clauser SB, Minasian LM, Dueck AC, et al. Development of the National Cancer Institute's Patient-Reported Outcomes Version of the Common Terminology Criteria for Adverse Events (PROCTCAE). J Natl Cancer Inst (2014) 106(9):dju24. doi: 10.1093/jnci/dju244

9. Nishimura Y, Yasuda M, Ocho K, Iwamuro M, Yamasaki O, Tanaka T, et al. Severe Gastritis After Administration of Nivolumab and Ipilimumab. Case Rep Oncol (2018) 11(2):549-56. doi: 10.1159/000491862

10. Wolchok JD, Chiarion-Sileni V, Gonzalez R, Rutkowski P, Grob J-J, Cowey $\mathrm{CL}$, et al. Overall Survival With Combined Nivolumab and Ipilimumab in Advanced Melanoma. N Engl J Med (2017) 377:(14):1345-56. doi: 10.1056/ NEJMoa1709684

11. Yip RHL, Lee LH, Schaeffer DF, Horst BA, Yang HM. Lymphocytic Gastritis Induced by Pembrolizumab in a Patient With Metastatic Melanoma. Melanoma Res (2018) 28(6):645-7. doi: 10.1097/CMR.0000000000000502

12. Kahler KC, Hassel JC, Heinzerling L, Loquai C, Mossner R, Ugurel S, et al. Management of Side Effects of Immune Checkpoint Blockade by Anti-CTLA4 and Anti-PD-1 Antibodies in Metastatic Melanoma. J Dtsch Dermatol Ges (2016) 14(7):662-81. doi: 10.1111/ddg.13047

13. Cramer P, Bresalier RS. Gastrointestinal and Hepatic Complications of Immune Checkpoint Inhibitors. Curr Gastroenterol Rep (2017) 19(1):3. doi: 10.1007/s11894-017-0540-6

14. Karamchandani DM, Chetty R. Immune Checkpoint Inhibitor-Induced Gastrointestinal and Hepatic Injury: Pathologists' Perspective. J Clin Pathol (2018) 71(8):665-71. doi: 10.1136/jclinpath-2018-205143

15. Johncilla M, Grover S, Zhang X, Jain D, Srivastava A. Morphological Spectrum of Immune Checkpoint Inhibitor Therapy Associated Gastritis. Histopathology (2019) 76(4):531-9. doi: 10.1111/his.14029

16. Cavalcante GC, Schaan AP, Cabral GF, Santana-da-Silva MN, Pinto P, Vidal AF, et al. A Cell's Fate: An Overview of the Molecular Biology and Genetics of Apoptosis. Int J Mol Sci (2019) 20(17):4133. doi: 10.3390/ijms20174133 
17. Boike J, Dejulio T. Severe Esophagitis and Gastritis From Nivolumab Therapy. ACG Case Rep J (2017) 4:e57. doi: 10.14309/crj.2017.57

18. Vindum HH, Agnholt JS, Nielsen AWM, Nielsen MB, Schmidt H. Severe Steroid Refractory Gastritis Induced by Nivolumab: A Case Report. World J Gastroenterol (2020) 26(16):1971-8. doi: 10.3748/wjg.v26.i16.1971

19. Larkin J, Chiarion-Sileni V, Gonzalez R, Grob J-J, Rutkowski P, Lao CD, et al. FiveYear Survival With Combined Nivolumab and Ipilimumab in Advanced Melanoma. N Engl J Med (2019) 381:(16):1535-46. doi: 10.1056/NEJMoa1910836

20. Verschuren EC, van den Eertwegh AJ, Wonders J, Slangen RM, van Delft F, van Bodegraven A, et al. Clinical, Endoscopic, and Histologic Characteristics of Ipilimumab-Associated Colitis. Clin Gastroenterol Hepatol (2016) 14 (6):836-42. doi: 10.1016/j.cgh.2015.12.028

21. Washington K, Jagasia M. Pathology of Graft-Versus-Host Disease in the Gastrointestinal Tract. Hum Pathol (2009) 40(7):909-17. doi: 10.1016/ j.humpath.2009.04.001

22. Myerson D, Steinbach G, Gooley TA, Shulman HM. Graft-Versus-Host Disease of the Gut: A Histologic Activity Grading System and Validation. Biol Blood Marrow Transplant (2017) 23(9):1573-9. doi: 10.1016/ j.bbmt.2017.05.017

23. Azad S, Malhotra V, Kirtani P, Choudhary D. Gastrointestinal Biopsies for Evaluation of Acute Graft-Versus-Host Disease in Allogeneic Hematopoietic Stem Cell Transplant Patients. Indian J Hematol Blood Transfus (2019) 35 (1):83-8. doi: 10.1007/s12288-018-0969-2

24. Salomao M, Dorritie K, Mapara MY, Sepulveda A. Histopathology of GraftVs-Host Disease of Gastrointestinal Tract and Liver: An Update. Am J Clin Pathol (2016) 145(5):591-603. doi: 10.1093/ajcp/aqw050

25. Postow MA, Sidlow R, Hellmann MD. Immune-Related Adverse Events Associated With Immune Checkpoint Blockade. N Engl J Med (2018) 378: (2):158-68. doi: 10.1056/NEJMra1703481

26. Naymagon S, Naymagon L, Wong S-Y, Ko HM, Renteria A, Levine J, et al. Acute Graft-Versus-Host Disease of the Gut: Considerations for the Gastroenterologist. Nat Rev Gastroenterol Hepatol (2017) 14(12):711-26. doi: $10.1038 /$ nrgastro.2017.126

Conflict of Interest: J-MP served as consultant and/or has received honoraria from Bristol-Myers Squibb and Novartis, and has received travel support from Bristol-Myers Squibb, Novartis and Therakos. HR is on the advisory board of Bristol-Myers Squibb, received honoraria from Roche and Bristol-Myers Squibb, received travel support from Philips, Roche, and Bristol-Myers Squibb, received grants from Bristol-Myers Squibb and holds shares of Bayer. EL served as consultant or/and has received honoraria from Amgen, Actelion, Roche, BristolMyers Squibb, Merck Sharp \& Dohme, Novartis, Janssen, Medac, Sanofi, and
Sunpharma, and travel support from Amgen, Merck Sharp \& Dohme, BristolMyers Squibb, Amgen, Pierre-Fabre, Sunpharma, and Novartis, outside the submitted work. SU received grants, personal fees, and non-financial support from Novartis, grants and non-financial support from Bristol-Myers Squibb; personal fees and non-financial support from Roche, personal fees from Merck Sharp \& Dohme, and non-financial support from Amgen, outside the submitted work. DS received grants and other support from Bristol-Myers Squibb, personal fees from Bristol-Myers Squibb during the conduct of the study, personal fees from Amgen, personal fees from Boehringer Ingelheim, personal fees from InFlarX, personal fees and other support from Roche, grants, personal fees and other support from Novartis, personal fees from Incyte, personal fees and other support from Regeneron, personal fees from 4SC, personal fees from Sanofi, personal fees from Neracare, personal fees from Pierre-Fabre, personal fees and other support from Merck-EMD, personal fees from Pfizer, personal fees and other support from Philogen, personal fees from Array, personal fees and other support from MSD Sharp \& Dohme, outside the submitted work. AR reported grants from Novartis, Bristol Myers Squibb, and Adtec, personal fees from Merck Sharp \& Dohme, and nonfinancial support from Amgen, Roche, Merck Sharp \& Dohme, Novartis, Bristol Myers Squibb, and Teva. LZ served as consultant and/or has received honoraria from Roche, Bristol-Myers Squibb, Merck Sharp \& Dohme, Novartis, Pierre-Fabre, and Sanofi, research funding to institution from Novartis, travel support from Merck Sharp \& Dohme, BristolMyers Squibb, Amgen, Pierre-Fabre, and Novartis, outside the submitted work.

The remaining authors declare that the research was conducted in the absence of any commercial or financial relationships that could be construed as a potential conflict of interest.

Publisher's Note: All claims expressed in this article are solely those of the authors and do not necessarily represent those of their affiliated organizations, or those of the publisher, the editors and the reviewers. Any product that may be evaluated in this article, or claim that may be made by its manufacturer, is not guaranteed or endorsed by the publisher.

Copyright (c) 2021 Placke, Rawitzer, Reis, Rashidi-Alavijeh, Livingstone, Ugurel, Hadaschik, Griewank, Schmid, Schadendorf, Roesch and Zimmer. This is an openaccess article distributed under the terms of the Creative Commons Attribution License (CC BY). The use, distribution or reproduction in other forums is permitted, provided the original author(s) and the copyright owner(s) are credited and that the original publication in this journal is cited, in accordance with accepted academic practice. No use, distribution or reproduction is permitted which does not comply with these terms. 